\title{
Black Turpentine Beetle, Dendroctonus terebrans (Olivier) (Insecta: Coleoptera: Curculionidae: Scolytinae) $)^{1}$
}

\author{
Albert E. Mayfield and John L. Foltz ${ }^{2}$
}

\section{Introduction}

The black turpentine beetle, Dendroctonus terebrans (Olivier), or BTB, is one of five common species of pine bark beetles in the southeastern United States. Black turpentine beetles bore into the inner bark of stressed or injured pines (Pinus spp.), where they breed and feed on phloem tissue. Adults are strongly attracted to volatile pine odors and readily breed in fresh stumps. Attacks on standing trees usually occur on the lower 1 to $2 \mathrm{~m}$ of the trunk or on large roots. Light attacks may kill only localized sections of phloem tissue, but numerous attacks per stem result in tree mortality. Infestations commonly occur in pine stands affected by recent logging activity (e.g., thinning), fire, mechanical injury, storm damage, climatic stress, or competition (USDA Forest Service 1985, Dixon 1986).

Historically, BTB has been a major pest of pines wounded or treated with herbicides in naval stores production (Smith and Lee 1972, Goldman et al. 1979). When local populations are sufficiently high, apparently healthy trees can be killed (Smith and Lee 1972). However, BTB infestations do not exhibit the rapid and devastating expansion characteristic of the closely related southern pine beetle, $D$. frontalis, and typically result in scattered, patchy and limited pine mortality.

\section{Distribution}

The BTB is found throughout the eastern United States from coastal New Hampshire south through Florida and west to Texas and Missouri. The northern range of BTB overlaps that of the red turpentine beetle (D. valens LeConte) which is similar in appearance and behavior.

\section{Description}

Adults are cylindrical, dark reddish-brown to black, and 5 to $8 \mathrm{~mm}$ in length (notably larger than the southern pine beetle, $D$. frontalis, which is 2 to 3 $\mathrm{mm}$ long). The head is convex in front and has clubbed antennae. The pronotum, the hard cover on top of the insect's midsection, widens posteriorly and does not conceal the head when viewed from above. The rear end of the wing covers is rounded (convex), which helps to distinguish Dendroctonus from the Ips engraver beetles.

1. This document is EENY-356 (originally published as DPI Entomology Circular 405), one of a series of Featured Creatures from the Entomology and Nematology Department, Florida Cooperative Extension Service, Institute of Food and Agricultural Sciences, University of Florida. Published: September 2005. This document is also available on Featured Creatures Website at http://creatures.ifas.ufl.edu. Please visit the EDIS Website at http://edis.ifas.ufl.edu.

2. Albert E. Mayfield, Florida Department of Agriculture and Consumer Services, Division of Forestry and John L. Foltz, Entomology and Nematology Department, Institute of Food and Agricultural Sciences, University of Florida, Gainesville, FL.

The Institute of Food and Agricultural Sciences (IFAS) is an Equal Opportunity Institution authorized to provide research, educational information and other services only to individuals and institutions that function with non-discrimination with respect to race, creed, color, religion, age, disability, sex, sexual orientation, marital status, national origin, political opinions or affiliations. U.S. Department of Agriculture, Cooperative Extension Service, University of Florida, IFAS, Florida A. \& M. University Cooperative Extension Program, and Boards of County Commissioners Cooperating. Larry Arrington, Dean 


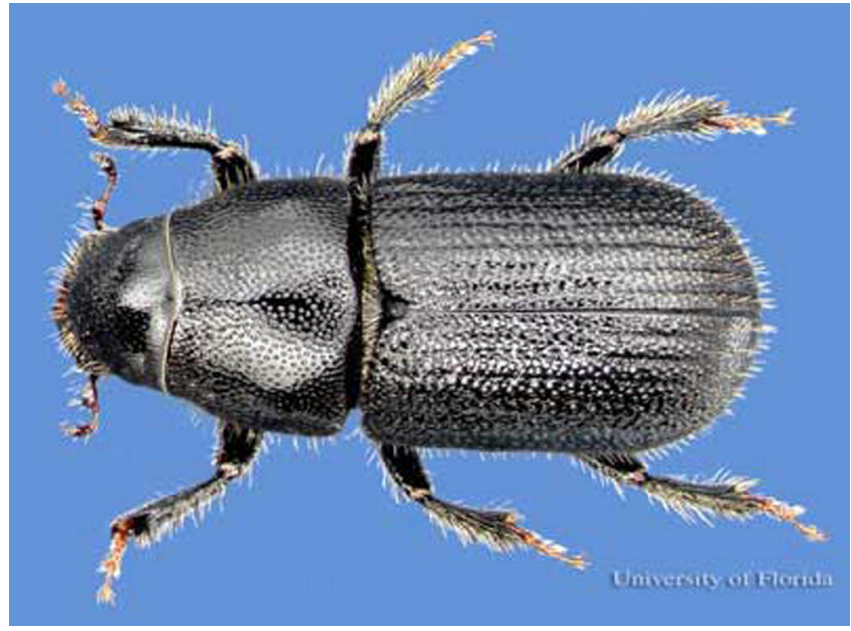

Figure 1. Dorsal view of an adult black turpentine beetle, Dendroctonus terebrans (Olivier). Its large size, trapezoidal pronotum, and rounded declivity distinguish it from all other bark beetles infesting pines in the South. Credits: David Almquist, University of Florida

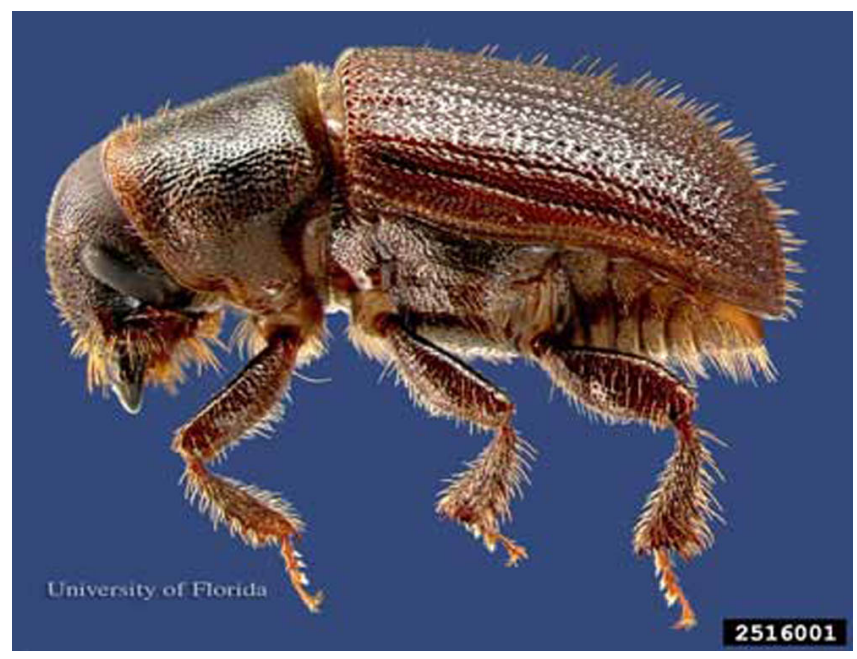

Figure 2. Lateral view of an adult black turpentine beetle, Dendroctonus terebrans (Olivier). Some adults have the red-brown coloration shown here although the majority are black. Credits: David Almquist, University of Florida

Mature larvae are about $12 \mathrm{~mm}$ long, creamy white, legless, and have reddish-brown heads. Pupae are waxy-white and of size similar to adults (Goyer et al. 1980, USDA Forest Service 1985).

\section{Biology}

Adult females initiate attack on the lower tree bole or root collar by boring a hole through the outer bark. Trees with sufficient resin pressure typically produce a large mass of resin and reddish boring dust called a "pitch tube" at the site of attack. A female beetle that successfully overcomes this resinous host

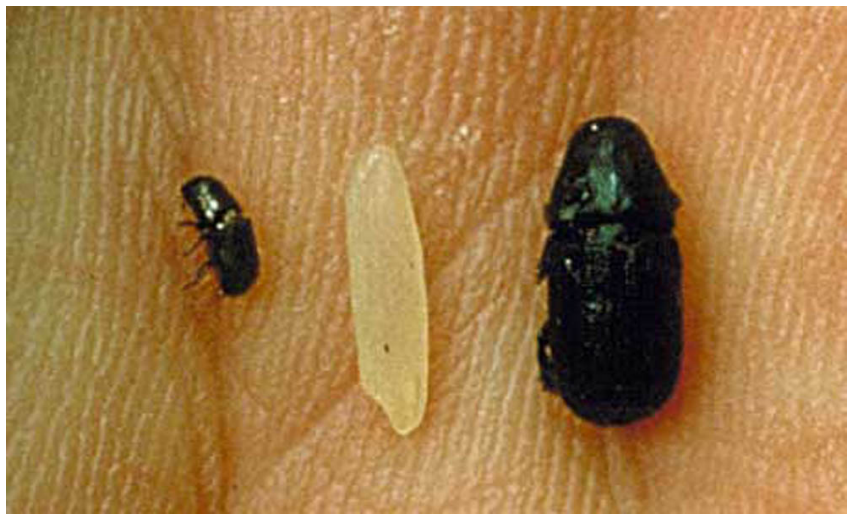

Figure 3. The adult black turpentine beetle, Dendroctonus terebrans (Olivier), (right) is 5 to $8 \mathrm{~mm}$ in length, much larger than the southern pine beetle, Dendroctonus frontalis Zimmermann, (left). A grain of rice (middle) is inserted for size comparison. Credits: Southern Forest Insect Work Conference Archives, www.forestryimages.org

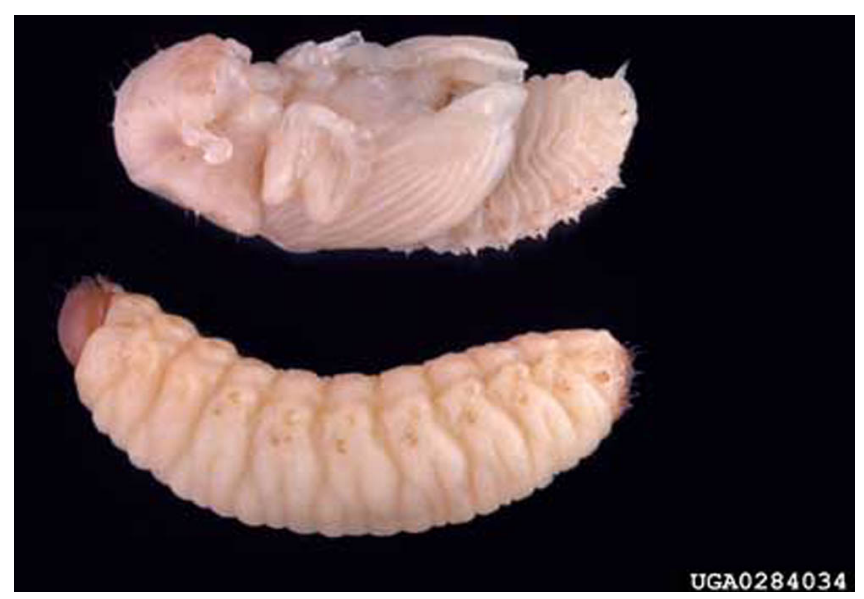

Figure 4. The pupa (top) and larva of the black turpentine beetle, Dendroctonus terebrans (Olivier). Credits: Gerald J. Lenhard, www.forestryimages.org

defense mechanism initiates gallery construction in the phloem and is then joined by a male. Tree colonization is mediated through beetle pheromones and volatile host attractants (Smith et al. 1993).

Adults spend about two weeks constructing galleries about $1 \mathrm{~cm}$ wide and 20 to $30 \mathrm{~cm}$ long on the face of the sapwood, typically in a downward direction from the entrance hole. The female then lays about 100 eggs in an elongate batch along one side of the gallery. Egg hatch occurs 10 to 14 days later.

Larvae feed side by side, creating a large, fan-shaped gallery or cavity that may fill with resin and frass. Mature larvae eventually tunnel off of the expanded cavity and create pupation cells. 


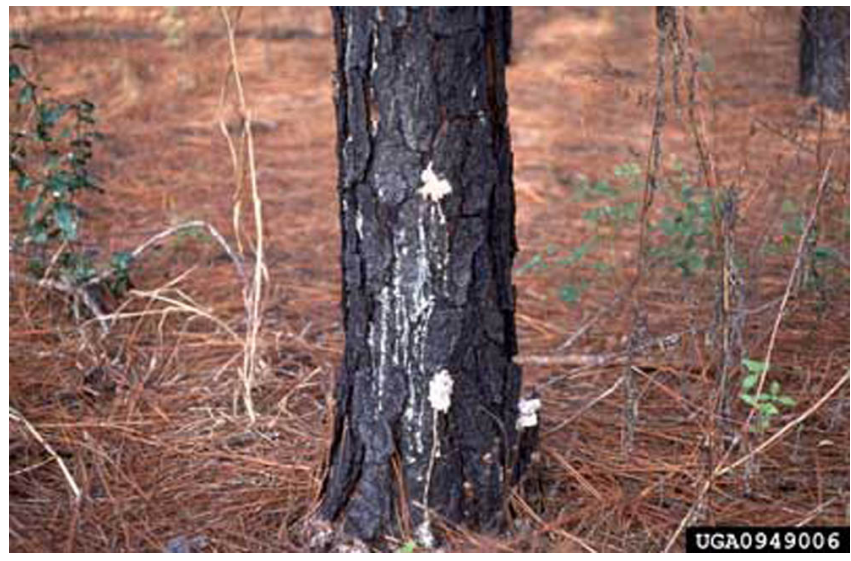

Figure 5. Pitch tubes of the black turpentine beetle, Dendroctonus terebrans (Olivier), occur on the lower trunk and may be as large as a half dollar. Credits: Wayne Dixon, FDACS-DPI, www.forestryimages.org

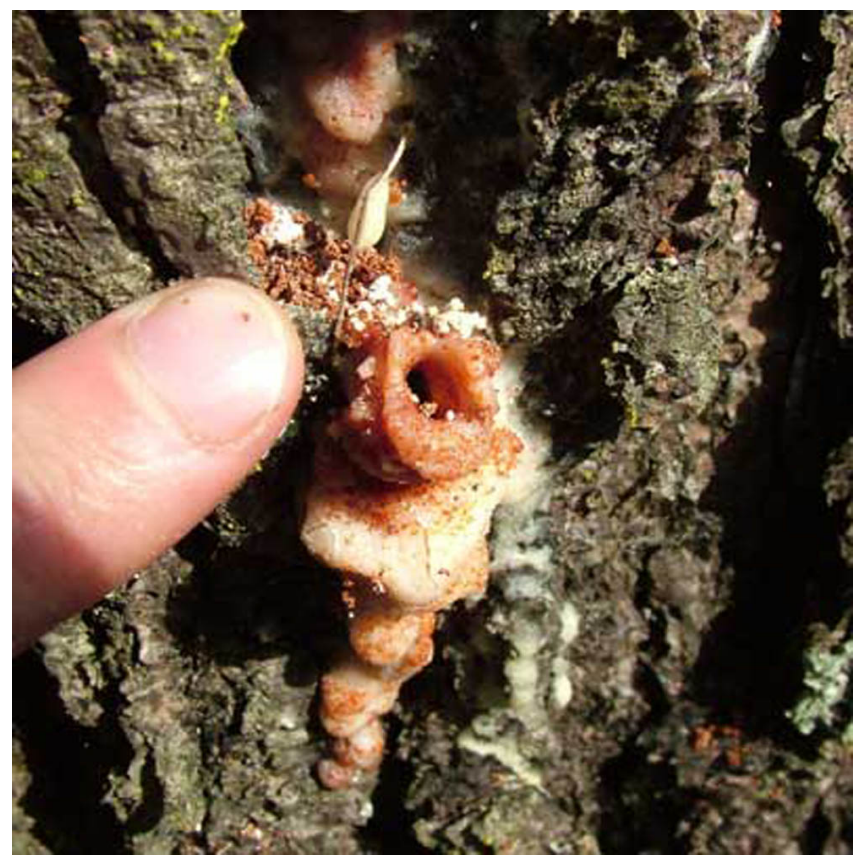

Figure 6. Close up of a pitch tube on slash pine caused by the black turpentine beetle, Dendroctonus terebrans (Olivier). Credits: Albert E. Mayfield III, FDACS

Young adults chew holes in the bark, exit their brood tree and disperse to colonize suitable host material. There are up to three overlapping generations per year in Florida and all life stages can be found year round (Smith and Lee 1972, Godbee and Franklin 1976, USDA Forest Service 1985). Fatzinger (1985) found peak trap captures in North Florida to occur in March, July and October.

The BTB is capable of vectoring blue stain fungi into the sapwood of its hosts (Barras and Perry 1971, Rane and Tattar 1987). Because BTB-attacked trees

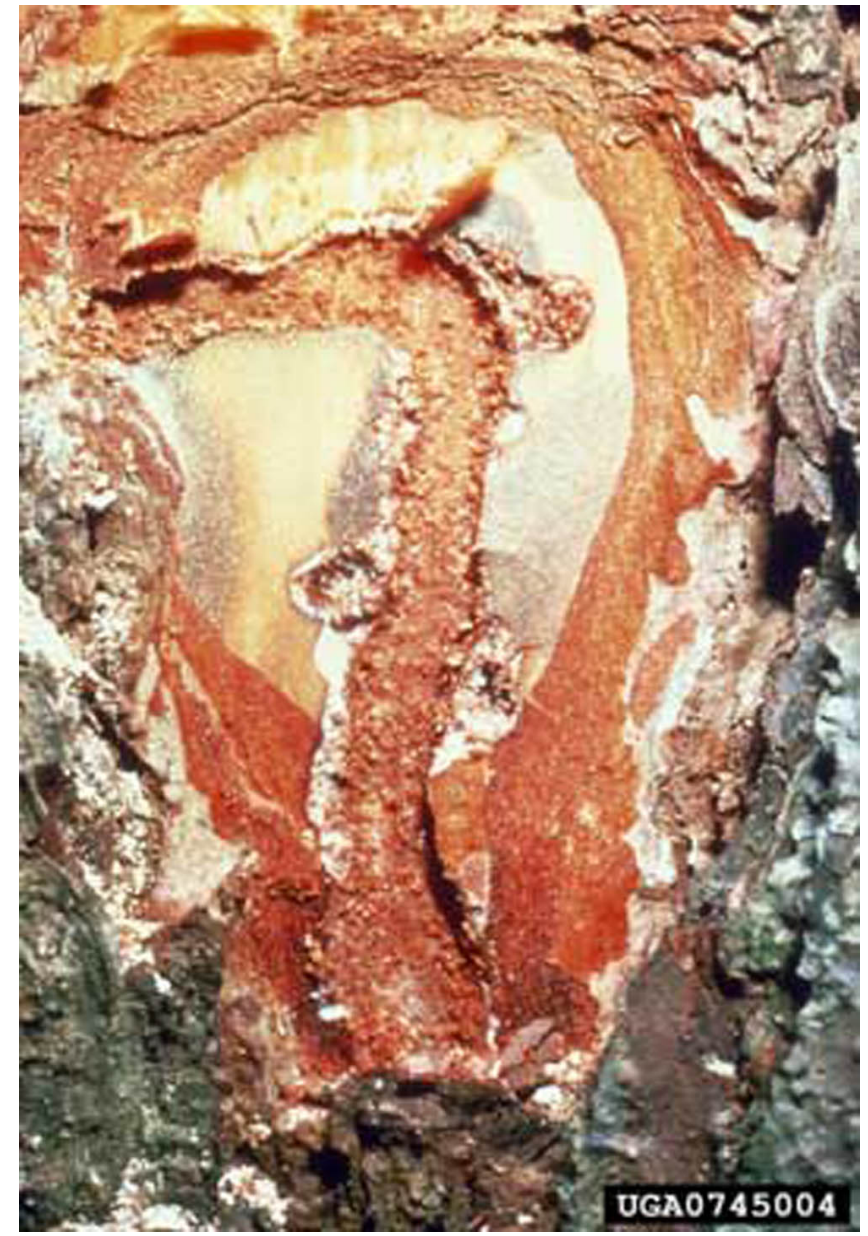

Figure 7. The egg gallery produced by adult black turpentine beetles, Dendroctonus terebrans (Olivier), starts with a short horizontal segment, then extends downward as the female produces eggs. Credits: Ronald F. Billings, Texas Forest Service; www.forestryimages.org

often survive, however, fungal colonization of the xylem may be less frequent, less pathogenic, or less extensive than blue stain introductions made by Dendroctonus frontalis and Ips engravers that result in rapid plugging of the xylem and hastened tree mortality. Tree mortality from BTB is, therefore, often a result of accumulated attacks over multiple generations or years.

\section{Hosts}

All species of southern pines (Pinus spp.) and red spruce (Picea rubens Sarg.) are suitable hosts. Slash (Pinus elliottii Engelm.) and loblolly (P. taeda L.) pines are common hosts in the southeastern U.S. (USDA Forest Service 1985). In other locations, native and non-native hosts include pitch pine ( $P$. rigida Mill.), eastern white pine ( $P$. strobus L.), black 


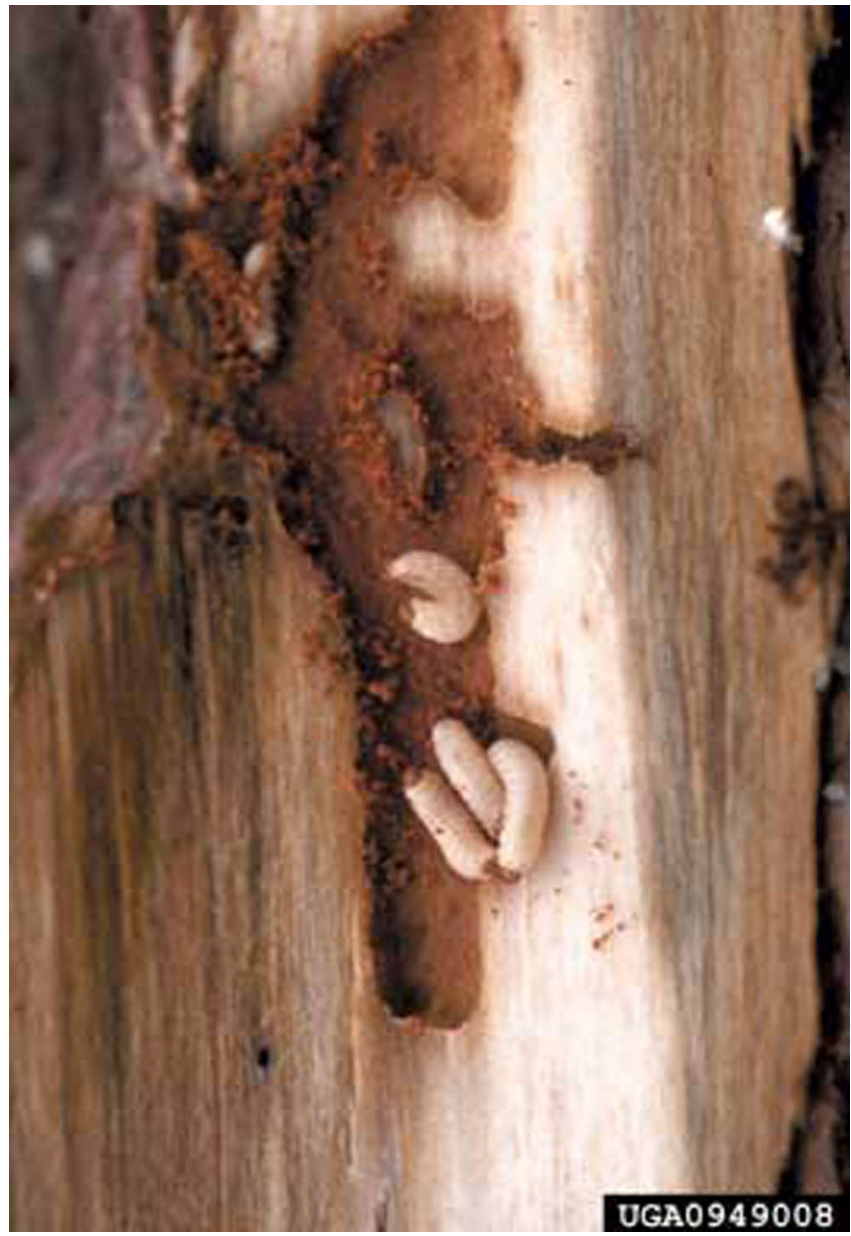

Figure 8. Feeding larvae of the black turpentine beetle, Dendroctonus terebrans (Olivier), and fan- or D-shaped larval gallery. Credits: James R. Meeker, FDACS; www.forestryimages.org

pine ( $P$. thunbergiana Franco) and Scots pine $(P$. sylvestris L.) (Wood 1982, Rane and Tattar 1987).

\section{Detection}

Signs and symptoms of BTB attack include:

- large (2 to $5 \mathrm{~cm}$ wide) pinkish-white, reddish-brown, or purplish-gray pitch tubes on the lower bole of the tree, which may exhibit an entrance hole 3 to $5 \mathrm{~mm}$ wide (pitch tubes, pitch tube);

- reddish-brown boring dust;

- accumulations of crystallized pitch pellets on the ground at the base of the tree;

- large vertical or fan-shaped galleries in the inner bark (gallery 1, gallery 2); and
- the entire tree crown gradually fading from green to yellow to red to brown.

\section{Prevention and Management}

Promoting and maintaining the health of pine trees and stands is the best way to prevent BTB attacks.

Preventative strategies in forest stands include:

- planting species that are appropriate to the site,

- thinning overstocked stands and maintaining an average basal area of less than 80 sq. ft. per acre,

- conducting prescribed burns and other treatments to control competing vegetation without damaging residual trees,

- harvesting damaged, declining, or recently-dead trees,

- conducting harvest operations during the cooler fall and winter months,

- avoiding root and bole damage to residual trees during management operations,

- keeping stump heights as low as possible, and

- keeping piles of logging slash and stacks of fresh pine firewood away from the base of live pines.

Thinning should be conducted before trees begin declining in growth due to root and crown competition. Avoid thinning when active bark beetle infestations are present within or adjacent to the stand. In areas where annosum root disease, caused by the fungus Heterobasidion annosum (Fr.:Fr.) Bref., has been or could be a problem, consider treating fresh-cut stump surfaces with borax following cool-season thinnings to help prevent root disease development in residual pines (Barnard 1999).

As for control, when BTB infestations are small and/or sparsely scattered throughout a stand, the best course of action is usually to let them die out on their own. Cutting and removing isolated infested trees or small "spot" infestations, as is done to control 
southern pine beetle infestations, is not recommended. In some cases such selective removals may exacerbate BTB problems by producing fresh host odors, fresh breeding material, and additional stress or injury to the residual stand. If tree mortality is progressing to unacceptable levels, a stand-level clearcut or a block removal of a generally infested area is preferable to selection harvests. Use of traps to control infestations and prevent attacks has not been successful (Fatzinger 1985).

For urban and residential landscape pines, preventative strategies include:

- avoiding compaction of, physical damage to, or pavement over the root zones of pines,

- avoiding trunk wounds,

- providing adequate spacing (4-6 m) between trees,

- minimizing competing vegetation beneath pines,

- maintaining proper soil nutrient status through an acidic needle or pine bark mulch over the root zone, and by not routinely watering turf grasses beneath pines, and

- providing supplemental deep watering during extended drought periods.

In some cases, the application of an approved insecticide to the lower 2 to $3 \mathrm{~m}$ of trunk may be warranted to protect high-value landscape trees from infestation. As a rule of thumb, trees on which the number of BTB pitch tubes is less than the diameter of the tree in inches are more likely to survive than those with greater attack densities; such trees may be good candidates for insecticidal treatment to prevent additional attacks.

Contact your local county Cooperative Extension Service office for current insecticide recommendations. Infested trees should be removed carefully to avoid injury to surrounding pines.

\section{Selected References}

Barnard EL. 1999. Annosum Root Rot of Pines in Florida. Plant Pathology Circular No. 398, Florida Department of Agriculture and Consumer Services, Division of Plant Industry, Gainesville. 5 p.

Barras SJ, Perry T. 1971. Leptographium terebrantis sp. nov. associated with Dendroctonus terebrans in loblolly pine. Mycopathologia et Mycologia applicata 43:1-10.

Dixon WN. 1986. Black turpentine beetle. Florida Department of Agriculture and Consumer Services, Division of Forestry, Gainesville. Forest and Shade Treet Pest Leaflet No. 4.

Fatzinger CF. 1985. Turpentine-baited traps capture black turpentine beetles and other forest Coleoptera but do not prevent attacks on pines. pp. 26-31. In Branham SJ, Thatcher RC. (eds.). Integrated pest management symposium: the proceedings. April 15-18, 1985. Asheville, NC. USDA Forest Service, Southern Forest Experiment Station. General Technical Bulletin SO-56.

Godbee JF, Franklin RT. 1976. Attraction, attack patterns and seasonal activity of the black turpentine beetle. Annals of the Entomological Society of America 69: 653-655.

Goldman SE, Cleveland GD, Parker JA. 1979. Lightwood induction and associated beetle attacks on slash pine. Forest Science 25: 80-83.

Goyer RA, Lenhard GJ, Nebeker TE, Jarrard LD. 1980. How to identify common insect associates of the southern pine beetle. Southern Pine Beetle Handbook. United States Department of Agriculture, Combined Forest Pest Research and Development Program. Agriculture Handbook No. 563.

Rane KK, Tattar TA. 1987. Pathogenicity of blue-stain fungi associated with Dendroctonus terebrans. Plant Disease 71: 879-883.

Smith MT, Salom SM, Payne TL. 1993. The southern pine bark beetle guild: an historical review of the research on the semiochemical-based communication system of the five principle species. 
Virginia Agricultural Experiment Station, Bulletin

No. 93-4. Blacksburg, VA. 106 p.

Smith RH, Lee, III RE. (1972). Black turpentine beetle. USDA Forest Service. Forest Pest Leaflet 12. http://www.barkbeetles.org/btb/btb12.html (23

November 2004)

USDA Forest Service. 1985. Insects of Eastern Forests. Misc. Publication No. 1426. Washington, DC. 608 p.

Wood SL. 1982. The bark and ambrosia beetles of North and Central America (Coleoptera:

Scolytidae), a taxonomic monograph. Great Basin

Naturalist Memoirs. No. 6. 1359 p. 